\title{
Plant species richness and composition in a trans-Himalayan inner valley of Manang district, central Nepal
}

\author{
Mohan P Panthi ${ }^{1 *}$, Ram P Chaudhary' and Ole R Vetaas ${ }^{2}$ \\ ${ }^{1}$ Central Department of Botany, Tribhuvan University, Kathmandu, NEPAL \\ ${ }^{2}$ UNIFOB - Global, University of Bergen, Nygaardsgaten 5, N-5015 Bergen, NORWAY \\ *For correspondence, email: panthimpp@hotmail.com, ole.vetaas@global.uib.no
}

\begin{abstract}
Species richness normally decreases with increasing elevation. However, a hump and a plateau have been documented in species richness curves in the Nepal Himalaya. We sampled species richness and composition in 80 plots located in the north and south aspects of the dry valley of Manang, a trans-Himalayan inner valley of Nepal, between 3000 and 4000 masl. We used regression and ordination to relate species richness and composition to the physical environment. Pinus wallichiana, Juniperus indica, Abies spectabilis, Betula utilis and Salix species are the dominant tree species. B. utilis is found only in the moist north aspect and Juniperus species are more common in the dry south aspect. Moisture is the most important determinant of species richness and composition. At the local level, our results show a plateau in species richness at the elevation range of 3000-4000 masl. There were significantly more species on the north aspect than on the south.
\end{abstract}

Key words: aspect, altitude, beta-diversity, ordination, species richness, soil moisture

Species richness is currently the most widely used measure of diversity (Stirling and Wilsey 2001). It is a simple and easily interpretable indicator of biological diversity (Peet 1974, Whittaker 1977). A complex of various factors determines species richness (Schuster and Diekmann 2005). Numerous studies have examined the relationships between plant species richness, climate and spatial variables. In broader scale, plant diversity correlates with size of area (Rosenzweig 1995), latitude (Currie and Paquin 1987), elevation (Stevens 1992, Merganic et al. 2004), precipitation (Whittaker and Niering 1965) and evapotranspiration (Currie 1991, Rohde 1992). Variation of species richness with elevation has been known for a long time. Many studies reported a decline in the number of species with increasing elevation (Brown 1988, Stevens 1992, Begon et al. 1996, Lomolino 2001). However, Rahbek (1995) showed a mid-altitude peak in species richness. Other studies, that found humped relationship between species richness and altitude, include Whittaker and Niering (1975), Liberman et al. (1996), Grytnes and Vetaas (2002) and Carpenter (2005).

Grytnes and Vetaas (2002) analyzed plant species richness along the Himalayan altitudinal gradient in Nepal. They concluded that interpolated species richness in the Himalaya showed a hump-shaped structure. The maximum richness of flowering plants of Nepal has been found between 1500 and 2500 masl. A study of total species richness from ca. 300 to 6000 masl in Nepal indicated a very little variation between 3000 and 4000 masl (Grytnes and Vetaas 2002) generating a high-elevation plateau. Observing this pattern of species richness on large scale, the aim of present work was to test this hypothesis on local level by sampling in a dry inner valley of Nepal Himalaya. The altitudinal range considered for the present work falls under the range of this plateau. The null hypothesis for the study was that there is no change in species richness between 3000 and 4000 masl.

Although the interpolated species richness gives one value for each elevation band, it is well known that richness may vary at different aspect in mountainous environment (Ferrer-Castan and Vetaas 2003). Aspect significantly influences richness and composition of plants. Literatures show that the primary impacts of aspect are expressed through regulating energy budgets and site moisture relationships. However, there is less generality in the effects of these impacts on the expression of vegetation (Bale et al. 1998). Mostly the north facing aspects get more moisture than the south facing aspects in the Himalayas (Vetaas 2000). In our knowledge, no studies have been done so far on the influence of aspect on species richness in the dry inner valley of Nepal Himalaya. The main aims of the present study are: (1) to describe plant species composition and relate it to environmental factors using ordination; (2) to test null hypothesis deduced from the interpolation, of no change in richness in between 3000 and 4000 masl; and (3) to evaluate the effect of aspect on species richness and composition.

Himalayan Journal of Sciences 4(6): 57-64, 2007

Available online at www.himjsci.com

Copyright@2007 by Himalayan Association for the

Advancement of Science 


\section{Materials and methods}

Study area The study area, a part of Annapurna Conservation Area, lies in Manang district of Nepal in the northwest Central Himalayas (Figure 1). The U-shaped inner valley extends east to west and is situated between $28^{\circ} 37^{\prime} 56^{\prime \prime}$ and 28 $39^{\prime} 55^{\prime \prime} \mathrm{N}$ latitude and $83^{\circ} 59^{\prime} 83^{\prime \prime}$ and $84^{\circ} 07^{\prime} 97^{\prime \prime}$ E longitude. The valley is surrounded by the Annapurna range on the south; Manasalu on the east; Peri, Himlung and Choya on the north; and Damodar and Muktinath on the west. The elevation ranges from 3000 to 3500 masl and the climate is dry, characteristic of the trans-Himalayan region. Due to the rain shadow of the Annapurna massif, the mean annual precipitation is ca. $400 \mathrm{~mm}$ (ICIMOD 1995). Average maximum and minimum temperatures, recorded at Jomsom (the nearest meteorological station approximately $12 \mathrm{~km}$ west of the study area with similar climatic conditions) were $7.9^{\circ} \mathrm{C}$ and $-1.75^{\circ} \mathrm{C}$ in winter and $22.6^{\circ} \mathrm{C}$ and $14.15^{\circ} \mathrm{C}$ in summer, respectively (DHM 1999). Snow covers the valley during winter. Soil moisture decreases from east to west in the valley, and the south facing slopes are significantly drier than those facing north (Bhattarai et al. 2004). The Marsyangdi River drains the valley.

Vegetation is dominated by Pinus wallichiana. On the north aspect $P$. wallichiana is abundant from the lower belt up to 3500 masl, above which Abies spectabilis and Betula utilis are common. Juniperus indica and Rosa sericea with other shrubs are dominant on the dry south facing slopes (Miehe 1982). The ground layer consists of scattered patches

of thorny cushion plant species such as Caragana, Astragalus with species of Primula, Saxifraga and Androsace. The riverbanks are occupied by Salix, Populus and Hippophae

\begin{tabular}{lllll} 
Table 1. DCA summary & & & & \\
\hline Axes & $\mathbf{1}$ & $\mathbf{2}$ & $\mathbf{3}$ & $\mathbf{4}$ \\
\hline Eigenvalues & 0.451 & 0.298 & 0.218 & 0.144 \\
\hline $\begin{array}{l}\text { Lengths of gradient } \\
\begin{array}{l}\text { Species-environment } \\
\text { correlation }\end{array}\end{array}$ & 0.045 & 2.844 & 2.182 & 2.156 \\
$\begin{array}{l}\text { Cumulative \% variance } \\
\text { of species data }\end{array}$ & 9.7 & 0.865 & 0.595 & 0.444 \\
\hline
\end{tabular}

Table 2. Inter-set correlation of main underlying environmental gradients with CA - axes

\begin{tabular}{llll} 
Axes & $\mathbf{1}$ & $\mathbf{2}$ & $\mathbf{3}$ \\
\hline Altitude & 0.51 & 0.70 & -0.027 \\
\hline Aspect & 0.62 & -0.41 & 0.32 \\
\hline Slope & 0.15 & -0.08 & -0.05 \\
Canopy & 0.20 & -0.69 & 0.22 \\
pH & -0.17 & 0.26 & -0.63 \\
Moisture & 0.77 & 0.056 & 0.32 \\
\hline
\end{tabular}

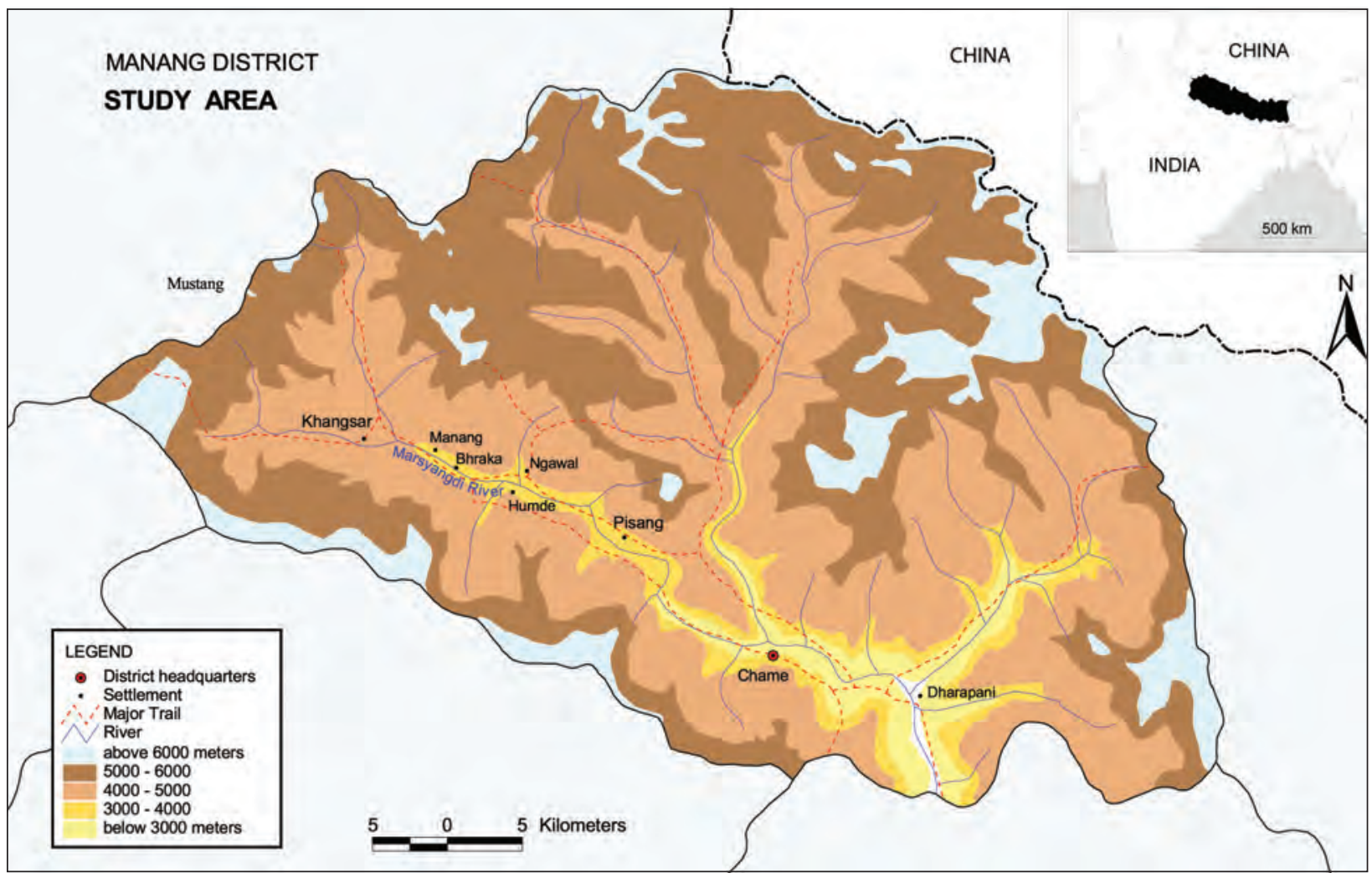

Figure 1. Location of the study area: Upper Manang, a trans-Himalayan dry inner valley in Manang, Central Nepal. (Source: Pawan Ghimire, Department of Geography, University of Bergen) 
Table 3. Total species richness

\begin{tabular}{|lllllll}
\hline $\begin{array}{l}\text { Altitudinal } \\
\text { range (masl) }\end{array}$ & $\begin{array}{l}\text { Total } \\
\text { species }\end{array}$ & $\begin{array}{l}\text { Total } \\
\text { species in } \\
\text { N aspect }\end{array}$ & $\begin{array}{l}\text { Total } \\
\text { species in } \\
\text { S aspect }\end{array}$ & $\begin{array}{l}\text { Species } \\
\text { common } \\
\text { in both }\end{array}$ & $\begin{array}{l}\text { Species } \\
\text { only in N } \\
\text { aspect }\end{array}$ & $\begin{array}{l}\text { Species } \\
\text { only in S } \\
\text { aspect }\end{array}$ \\
\hline $3200-3300$ & 31 & 22 & 17 & 8 & 14 & 9 \\
\hline $3300-3400$ & 36 & 21 & 28 & 13 & 8 & 15 \\
\hline $3400-3500$ & 33 & 25 & 18 & 10 & 15 & 8 \\
\hline $3500-3600$ & 31 & 24 & 13 & 6 & 18 & 7 \\
\hline $3600-3700$ & 29 & 21 & 14 & 6 & 15 & 8 \\
\hline $3700-3800$ & 29 & 21 & 12 & 4 & 17 & 8 \\
\hline $3800-3900$ & 34 & 26 & 15 & 7 & 19 & 8 \\
\hline $3900-4000$ & 39 & 29 & 20 & 10 & 19 & 10 \\
\hline Total & 68 & 58 & 46 & 36 & 22 & 10 \\
\hline
\end{tabular}

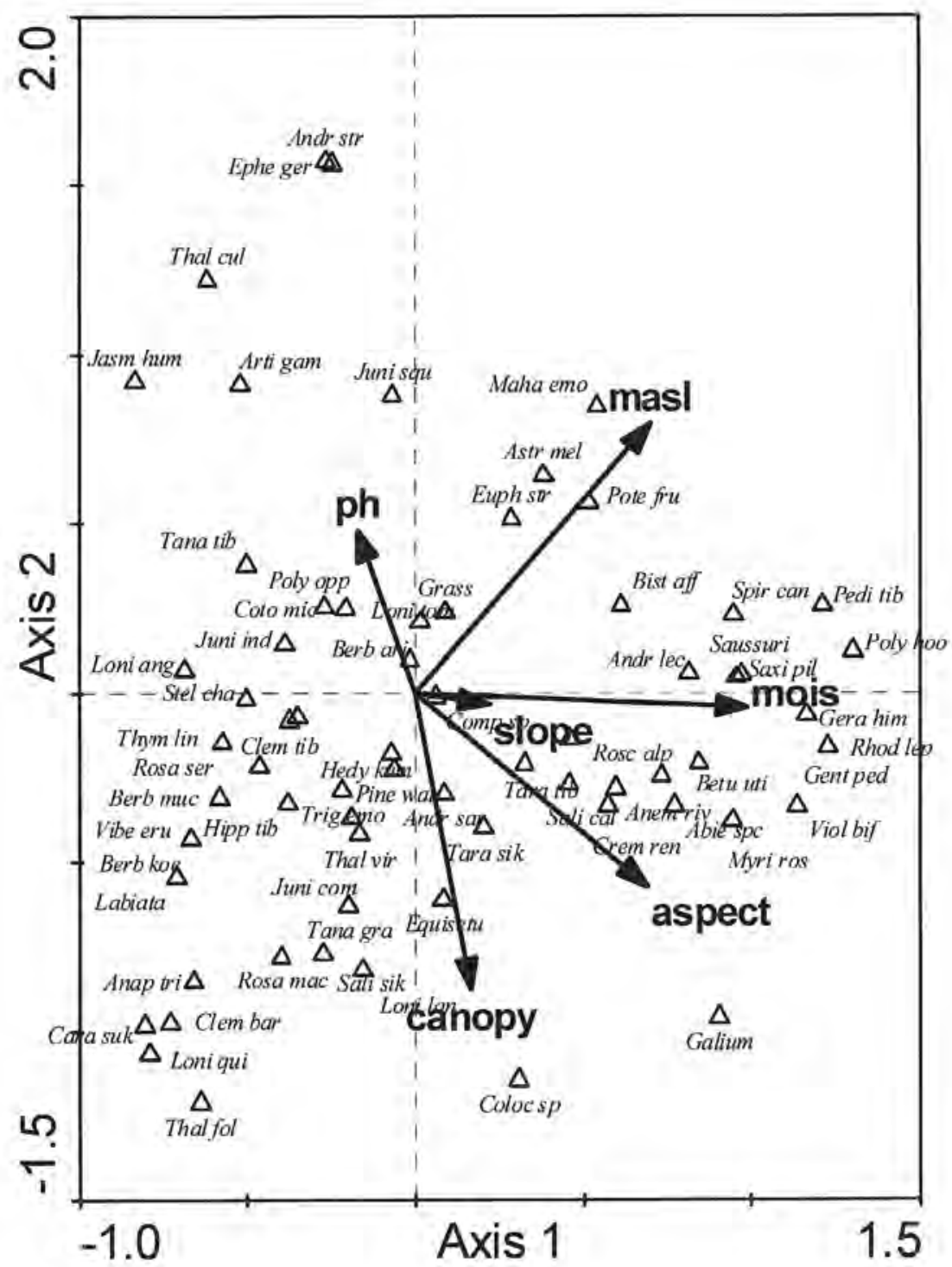

Figure 2. Ordination biplot diagram for species and environmental variables. Plots are displayed by triangles and species are labeled by the first four letters of the generic name and three letters of the species name. Complete plant names are given in Appendix 1. Right side of the axis 1 represents north aspect and left side represents south aspect of the study area. species. Picea smithiana and Tsuga dumosa grow on at few locations on the north aspect of the valley.

Field sampling Data on species composition and richness of vascular plants were collected from 80 plots during May and June 2004. Plots (10 m x $10 \mathrm{~m}$ ) were located using a stratified random sampling design. The sampling was done at $100 \mathrm{~m}$ intervals from 3200-4000 masl on the north and south aspects of the valley. Individuals of all species rooted in the plots were counted. The following environmental variables were assessed for each plot: percentage of canopy cover of each tree species (visual estimation), $\mathrm{pH}$ and moisture of soil (using a DM 15 gauge, Takemura Electric Works Ltd., Japan), elevation (using an altimeter), and slope (with a clinometer). The nomenclature follows Hara et al. (1978, 1982), Hara and Williams (1979), and Press et al. (2000). All the voucher specimens have been deposited at the Tribhuvan University Central Herbarium (TUCH), Kathmandu, Nepal.

Numerical methods We used ordination to analyze species composition and beta diversity. Detrended correspondence analysis (DCA) is a widely used indirect ordination method (e.g. Økland and Eilertsen 1996, Exner et al. 2002, Lepš and Šmilauer 2003) and provides an effective approximation of the underlying environmental gradients (ter Braak 1995). DCA (Hill and Gauch 1980) was used to describe the total species composition and differences between the two aspects and to estimate the compositional gradient length in SD-units (i.e. beta diversity) (Hill 1973, Lepš and Šmilauer 2003). A preliminary analysis showed SD-unit greater than two and no archeffect; we used correspondence analysis (CA) to relate species composition to the environmental factors. This was done on the total data (80 plots) and on the two aspects separately $(n=40)$.

We also performed regression on the total data set in order to analyze species richness. We used species richness as the response variable and the principal environmental factors (moisture, aspect, $\mathrm{pH}$, canopy) as explanatory variables. We checked distribution on normal Gaussian and Poisson models and selected the former as more suitable. We 
also performed separate analyses for each aspect in relation to canopy cover, elevation and moisture. The difference in mean species richness between the two aspects was tested by student t-test. We analyzed the data using S-PLUS (Anonymous 2002), as well as CANOCO version 4.5 (ter Braak 2002) and its graphical programme CANODRAW (Smilauer 2002).

\section{Results}

Species composition DCA results (Table 1) show that the compositional gradient lengths of the first and second axes are 3.0 and 2.8 (eigenvalues 0.451 and 0.298 ), respectively. The DCA summary reveals that the first gradient is by far the longest, explaining $9.7 \%$ of the total species variability, whereas the second and higher axes explain much less. Pinus wallichiana was the only dominant tree species found on both north and south aspects. It is located near the central position of the species plot of ordination diagram (Figure 2). Juniperus species were located towards the negative side of first axis, i.e. on the dry side, while Betula utilis and Abies spectabilis appeared towards positive side of first axis, which is moister. $B$. utilis was reported only from the north aspect. Other woody species as Rosa sericea and Lonicera species were found at low elevations of both aspects, while Rhododendron lepidotum was noticed at high elevation of the north aspect. At least one or two species of Berberis were reported throughout the altitudinal gradient. Among herbs, Polygonatum oppositifolium, Stellera chamaejasme, Androsace spp., Potentilla fruticosa, and Primula spp. were common.

Correspondence analysis (CA) revealed that moisture, soil $\mathrm{pH}$ and canopy cover are the main underlying environmental gradients for species composition. The first and second axes are well correlated with the environmental factors ( $r=0.855$ and 0.865 , respectively) and the correlation for the other axes is considerably lower (not shown). Moisture has the strongest correlation with the first axis (Table 2, Figure 2). The second axis correlates with canopy cover and the third axis with $\mathrm{pH}$. The south aspect is relatively dry with high $\mathrm{pH}$ (6.8). The two spatially independent factors - elevation and aspect - were correlated with both first and second axes.

Species richness Sixty eight plant species belonging to 50 genera and 31 families (Appendix 1) were recorded. The number of species increased from 3200 to 3400 masl, followed by a gradual decrease up to 3800 masl. Above 3800 masl, the number of species again increases towards high elevation (3900-4000 masl, Table 3). In general, however, variation in species richness as function of elevation between 3000 and 4000 masl is not significant, and a high-elevation plateau in richness is found. Species richness is correlated with moisture ( $r=0.232$, Figure 3 ). Normally, south aspect is dry and north aspect is moist. Mean species numbers on the south and north aspects are 10.0 and 11.8, respectively. Species richness is significantly higher on the north aspect than on the south $(\mathrm{t}=-2.86, p=0.005$ for $78 \mathrm{df}$ ). The total number of species reported from the north aspect is 58 , with beta diversity 3.10 and eigenvalue 2.7. The total number of species from the south aspect is 46 with beta diversity 2.97

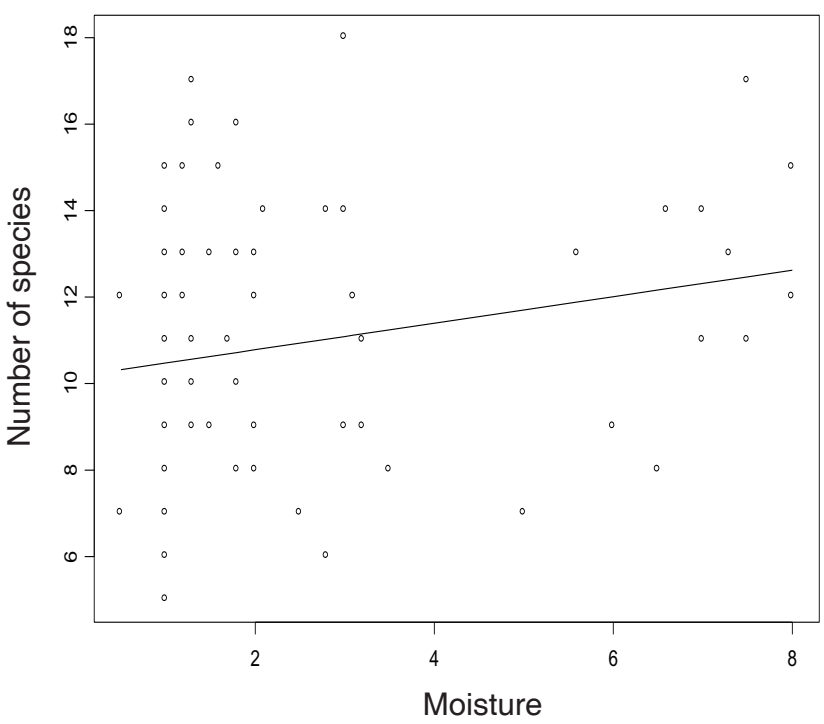

Figure 3. Correlation of total species richness with moisture (arbitrary unit), $\mathrm{r}=0.232$

and eigenvalue 2.1. In total 36 species are common to the both aspects (Table 3).

\section{Discussion}

A monotonic decline in the number of species with increasing elevation has often been considered a general pattern (Brown 1988, Stevens 1992). However, our results indicate that species richness does not follow this pattern in our study sites. A plateau in species number is observed between 3000 and 4000 masl. This is consistent with patterns for overall interpolated species richness in the Nepal Himalaya found by Grytnes and Vetaas (2002) and Vetaas and Grytnes (2002). Studies that have employed the interpolative method on elevation gradients are becoming more common, as for example Fleishman et al. (1998) for butterflies and Grytnes and Vetaas (2002) for plants. Our empirical results confirm that there is a little change in species richness between 3000 and 4000 masl. The small variation in species number may be due to seasonal movement of animals. Livestock (yak, horse, mule, sheep and goats) are brought to alpine pasture to graze during the summer months of April to September (Bhattarai et al. 2004) and stay in the valley bottom during the winter. Seed dispersal via animal dung, hooves and coats (Sykora et al. 1990, Poschlod et al. 1998, Moe 2001) may be important in reducing disparities in species number along the elevation gradient.

The striking high-elevation plateau of species richness might seem anomalous, but similar patterns have been found previously, particularly in ornithological surveys. The species richness of birds in Manu National Park of Peru (Patterson et al. 1998) and also in Bolivia (Herzog et al. 2005) show similar plateau with identical richness values. However, this phenomenon is still not well understood (Herzog et al. 2005). Gill et al. (1999), describing the changes of plant diversity after fire, mention a period of plateau formation in species richness. Fire is not used as a management tool at our 
study site. Although there were occasional forest fires, their influence on species richness is uncertain.

Moisture is the main environmental factor impacting plant species richness and composition. There is a significant $(r=0.232)$ relationship between moisture and species richness. Moisture is positively correlated with canopy and negatively correlated with $\mathrm{pH}$ (Figure 2). Soil $\mathrm{pH}$ is also related to the availability of soil nutrients, but has no apparent relation to species richness. Increase in species richness from acidic to neutral soil is common in temperate forests (Palmer 1990, Pausas 1994) and a pattern of richness increasing with higher pH has been reported in the Arctic tundra (Gough et al. 2000). Grime (1973) found that the maximum number of species in unmanaged grassland occurs at a $\mathrm{pH}$ of $6.1-6.5$, with species richness declining in both acidic and alkaline soils. Canopy is also a significant factor, probably through its influence on the light intensity reaching the ground, as suggested by several authors (e.g., Spurr and Barnes 1973, Tilman 1985).

Aspect regulates the quantity and duration of soil moisture, partly through temperature (Parker 1991). The northern aspect is moister with more canopy cover than the southern aspect; these two factors both have a positive influence on species richness. An understanding of aspect is important in forest management and planning (Bale and Charley 1994), because of its influence on tree diameter growth (Verbyla and Fisher 1989) and forest productivity (Hutchins et al. 1976). The natural forest in the inner valley extends from 3000 to 4200 masl in the north aspect, while its upper limit is below 4000 masl in the south aspect. Aspect also relates with species richness. Since the influence of aspect on species richness in the inner valleys of the Himalayas has not been studied adequately, we could not make further comparisons.

As elevation increases, temperature decreases with the reduction of evapotranspiration on the slopes (Eklund et al. 2000). The elevation contributes to a difference in mean temperature of up to $3.0^{\circ} \mathrm{C}$ (lapse rate $0.51^{\circ} \mathrm{C} / 100$ $\mathrm{m}$, Vetaas 2000). In an empirical analysis involving North American plants and animals, Currie (1991) concludes that potential evapotranspiration is the best predictor of animal species richness. For tree species, actual evapotranspiration was shown to be the best predictor of richness, with a monotonically increasing relationship (Currie and Paquin 1987, Francis and Currie 1998).

The beta diversity of the north aspect (3.10) exceeds that of the south aspect (2.1), suggesting greater species turnover on the north side. The turnover in species is mainly attributable to high moisture, along with other supporting environmental factors. Besides the common species found on both the north and south aspects, a total of 22 species reported from the north aspect were not found in the south aspect. In dry habitats, species number increases towards the relatively wetter areas, as observed by Kassas and Zahran (1971) in Egypt, and byVetaas (1993) in Sudan. In New Zealand total tree species richness was found to increase with soil and atmospheric moisture (Leathwick et al.1998). In dry and semi arid areas moisture is often the limiting factor, and thus has a strong influence on species richness (Olsvig-Whittaker et al. 1983, Belsky et al. 1989). The difference in microclimate between the north and south aspects is associated with differences in the composition and richness of species, which can be compared with the findings of Pook and Moore (1966) on the influence of aspect on the composition and structure of forest on Black mountain, Canberra.

In short, total species richness shows a plateau between 3000 and 4000 masl at the local level. Species richness is significantly higher on the north facing slope than on the south facing slope. It also can be concluded that moisture and factors influencing evaporation (i.e. canopy and aspect), are the main environmental factors influencing species composition and richness in the dry inner valley of the transHimalaya.

\section{Acknowledgements}

We would like to acknowledge the cooperation of the people of Manang Valley. We thank BK Ghimire for his energetic help during the field work and Pawan Ghimire for providing a map of Manang. Our research was sponsored by the Norwegian Council for Higher Educations Programme for Development Research and Education (NUFU Project ID: PRO 04/2002), and OR Vetaas was funded by Norwegian Research Council (project no.148910/730). MP also thanks the Central Department of Botany, TU, for laboratory facilities, and Tribhuvan University, Nepal for granting a study leave.

\section{References}

Anonymous. 2002. S-Plus 6.1 for Windows, professional ed. release 1. Insightful Corp. Seattle, WA

Bale CL and JL Charley. 1994. The impact of aspect on forest floor characteristics in some eastern Australian sites. Forest Ecology and Management 67: 305-317

Bale CL, JB Williams and JL Charley. 1998. The impact of aspect on forest structure and floristics in some eastern Australian sites. Forest Ecology and Management 110 (1-3): 363-377

Begon M, J Harper and CR Towsend. 1996. Ecology: Individuals, Populations and Communities. Second edition. Blackwell, Oxford. $1068 \mathrm{p}$

Belsky AJ, RG Amundson, JM Duxbury, SJ Riha, AR Ali and SM Mwonga. 1989. The effects of trees on their physical, chemical and biological environment in a semi-arid savanna in Kenya. Journal of Applied Ecology 26: 1005-1024

Bhattarai KR, OR Vetaas and JA Grytnes. 2004. Relationship between plant species richness and biomass in an arid sub-alpine grassland of the central Himalayas, Nepal. Folia Geobotanica 39: $57-71$

Brown JH. 1988. Species diversity. In: Myers AA and PS Giller (eds), Analytical biogeography: An integrated approach to the study of animal and plant distribution. Chapman and Hall, New York. p 57-89

Carpenter C. 2005. The environmental control of plant species density on a Himalayan elevation gradient. Journal of Biogeography 32: 999-1018

Currie DJ. 1991. Energy and large-scale patterns of animal - and plant - species richness. American Naturalist 137: 27-49

Currie DJ and V Paquin. 1987. Large scale biogeographical patterns of species richness of trees. Nature 329: 326-327

DHM. 1999. Climatological records of Nepal 1995-1996. Department of Hydrology and Metrology, Kathmandu, Nepal

Eklund A, M Gardelin and A Lindroth. 2000. Simulated and measured winter evaporation in a boreal forest: Assessment of the HBV model. Upsala: The XXI Nordic Hydrological Conference. NHP Report No. 46: 332-338

Exner A, W Willner and G Grabherr. 2002. Picea abies and Abies alba forests of the Austrian Alps: Numerical classification and ordination. Folia Gebotanica 37: 383-402

Ferrer-Castan D. and OR Vetaas. 2003. Floristic variation, chorological types and diversity: Do they correspond at broad and local scales? Diversity and Distributions 9: 221-235 
Fleishman F, GT Austin and AD Weiss. 1998. An empirical test of Rapoport's rule: Elevational gradients in montane butterfly communities. Ecology 79: 2472-2483

Francis AP and DJ Currie. 1998. Global patterns of tree species richness in moist forests: Another look. Oikos 81: 598-602

Gill AM, JCZ Woinarski and A York. 1999. Australia's BiodiversityResponses to Fire: Plants, Birds and Invertebrates. Biodiversity technical paper, no.1. Department of the Environment and Heritage, Government of Australia

Gough L, GR Shaver, J Carroll, DL Royer and JA Laundre. 2000. Vascular plant species richness in Alaskan arctic tundra: The importance of soil pH. Journal of Ecology 88: 54-66

Grime JP. 1973. Competitive exclusion in herbaceous vegetation. Nature 242: 344-347

Grytnes JA and OR Vetaas. 2002. Species richness and altitude: A comparison between Null models and interpolated plant species richness along the Himalayan altitudinal gradient, Nepal. American Naturalist 159: 294-304

Hara H, WT Stearn and HJ Williams. 1978. An enumeration of the flowering plants of Nepal, Vol.1. British Museum Natural History, London

Hara $\mathrm{H}$ and HJ Williams. 1979. An enumeration of the flowering plants of Nepal, Vol.2. British Museum Natural History, London

Hara H., AO Chater and HJ Williams. 1982. An enumeration of the flowering plants of Nepal, Vol.3. British Museum Natural History, London

Herzog SK, M Kessler and K Bach. 2005. The elevation gradient in Andean bird species richness at the local scale: A foot hill peak and a high elevation plateau. Ecography 28: 209-222

Hill MO. 1973. Reciprocal averaging: An eigenvector method of ordination. The Journal of Ecology 61: 237-249

Hill MO and HG Gauch. 1980. Detrended correspondance analysis: An improved ordination technique. Vegetatio 42: 47-58

Hutchins RB, RL Blevins, JD Hill and EH White. 1976. The influence of soils and microclimate on vegetation of forested slopes in eastern Kentucky. Soil Science 121: 234-241

ICIMOD. 1995. Iso-climatic map of mean annual precipitation. International Centre for Integrated Mountain Development (ICIMOD), Kathmandu, Nepal

Kassas M and MA Zahran. 1971. Plant life on the costal mountains of the Red Sea, Egypt. Journal of Indian Botanical Society 50a: 571-586

Leathwick JR, BR Burns and BD Clarkson. 1998. Environmental correlates of tree alpha-diversity in New Zealand primary forests. Ecography 21: 235-246

Lepš J and P Šmilauer. 2003. Multivariate Analysis of Ecological Data using CANOCO. Cambridge University Press, Cambridge $269 \mathrm{p}$

Liberman D, M Liberman, R Peralta and GS Hartshorn. 1996. Tropical forest structure and composition on large-scale altitudinal gradient in Costa Rica. The Journal of Ecology 84: 137-152

Lomolino MV. 2001. Elevation gradients of species-density: Historical and prospective views. Global Ecology and Biogeography 10: 3-13

Merganic J, HD Quednau and S Smelko. 2004. Relations between selected geomorphology features and tree species diversity of forest ecosystems and interpolation on a regional level. European Journal of Forest Research 123: 75-85

Miehe G. 1982. Vegetationsgeographische Untersuchungen im Dhaulagiri in Annapurna- Himalaya. Dissertationes Botanicae 66(i-xi): 1-224

Moe D. 2001. Examples of traffic in the Alps in the past elucidated by pollen analysis. (Extended abstract). AmS-Varia (Stravanger) 37: 99-102

Økland RH and O Eilertsen. 1996. Dynamics of understory vegetation in an old-growth boreal coniferous forest, 1988-1993. Journal of Vegetation Science 7: 747-762

Olsvig-Whittaker L, M Shachak and A Yair. 1983. Vegetation patterns related to environmental factors in a Negev watershed. Vegetatio 54:153-165

Palmer MW. 1990. Spatial scale and patterns of vegetation, flora and species richness in hardwood forests of the North Carolina Piedmont. COENOSES 5: 89-96
Parker KC. 1991. Topography, substrate and vegetation patterns in the northern Sonoran desert. Journal of Biogeography 18: 151-163

Patterson BD, DF Stotz, S Solari, JW Fitzpatrick and V Pacheco. 1998. Contrasting patterns of elevational zonation for birds and mammals in the Andes of south-eastern Peru. Journal of Biogeography 25: 593-607

Pausas JG. 1994. Species richness patterns in the understorey of Pyrenean Pinus sylvestris forest. Journal of Vegetation Science 5: 517-524

Peet RK. 1974. The measurement of species diversity. Annual Review of Ecology and Systematics 5: 285-307

Pook EW and CWE Moore. 1966. The influence of aspect on the composition and structure of dry sclerophyll forest on Black Mountain, Canberra, A.C.T. Australian Journal of Botany 14: 223-242

Poschlod P, S Kiefer, U Trankle, S Fischer and S Bonn. 1998. Plant species richness in calcareous grasslands as affected by dispersability in space and time. Applied Vegetation Science 1: $75-90$

Press JR, KK Shrestha and DA Sutton. 2000. Annotated checklist of the flowering plants of Nepal. The Natural History Museum, London. $430 \mathrm{p}$

Rahbek C. 1995. The elevation gradient of species richness: A uniform pattern? Ecography 18: 200-205

Rohde K. 1992. Latitudinal gradients in species diversity: The search for primary cause. Oikos 65: 514-527

Rosenzweig ML. 1995. Species diversity in space and time. Cambridge, UK: Cambridge University Press. $458 \mathrm{p}$

Schuster B and M Diekmann. 2005. Species richness and environmental correlates in deciduous forests of Northwest Germany. Forest Ecology and Management 206: 1973-205

Smilauer P. 2002. CANODRAW for Window 4.0

Spurr SH and BV Barnes. 1973. Forest Ecology. Second edition. Ronald, New York. 571p

Stevens GC. 1992. The elevationonal gradient in altitudinal range: an extension of Rapoport's latitudinal rule to altitude. Amerian Naturalist 140: 893-911

Stirling G and B Wilsey. 2001. Empirical Relationships between Species Richness, Evenness, and Proportional Diversity. American Naturalist 158(3): 286-299

Sykora KV, G van der Krogt and J Rademakers. 1990. Vegetation change on embankments in the southern part of the Netherlands under the influence of different management practices (in particular sheep grazing). Biological Conservation 52: 49-81

ter Braak CJF. 1995. Ordination. In: Jongman RHG, ter Braak CJF and van Tongeren OFR (eds), Data analysis in community and landscape ecology. Cambridge University Press, Cambridge. $\mathrm{p}$ 91-173

ter Braak CJF. 2002. CANOCO-Version 4.5. Wageningen

Tilman D. 1985. The resource-ratio hypothesis of plant succession. American Naturalist 125: 827-852

Verbyla DL and RF Fisher. 1989. Effects of aspect on ponderosa pine height and diameter growth. Forest Ecology and Management 27: 93-98

Vetaas OR. 1993. Effect of spatial arrangement of environmental variables on ordination results from a disturbed humidity gradient in Northeastern Sudan. COENOSES 8(1): 27-37

Vetaas OR. 2000. Comparing species temperature response curves: Population density versus second-hand data. Journal of Vegetation Science 11: 659-666

Vetaas OR and JA Grytnes. 2002. Distribution of vascular plants species richness and endemic richness along the Himalayan elevation gradient in Nepal. Global Ecology and Biogeography 11: 291-301

Whittaker RH. 1977. Evolution of species diversity in land plant communities. Evolutionary Biology 10: 1-67

Whittaker RH and WA Niering. 1965. Vegetation of the Santa Catalina Mountains, Arizona.II. A gradient analysis of the south slope. Ecology 46: 429-452

Whittaker RH and WA Niering. 1975. Vegetation of the Santa Catalina Mountains, Arizona.V. Biomass production and diversity along the elevational gradient. Ecology 56: 771-790 
APPENDIX: 1. Plants recorded from sampled plots

\begin{tabular}{|c|c|c|}
\hline Abbreviation & Plant name & Family \\
\hline Abie spe & Abies spectabilis (D. Don) Mirb. & Pinaceae \\
\hline Anap tri & Anaphilis triplinervis (Sims.) C. B. Clarke & Compositae \\
\hline Andr leh & Androsace lehmannii Wall. ex Duby & Primulaceae \\
\hline Andr sar & Androsace sarmentosa Wall. & Primulaceae \\
\hline Andr str & Androsace strigillosa Franch. & Primulaceae \\
\hline Anem riv & Anemone rivularis Buch.-Ham. ex DC. & Ranunculaceae \\
\hline Arti gam & Artemisia gemelinii Web. Ex Stechm & Compositae \\
\hline Astr mel & Astragalus melanostachys Benth. ex Bunge. & Leguminosae \\
\hline Berb ari & Berberis aristata DC. & Berberidaceae \\
\hline Berb koe & Berberis koehneana C.K. Schneid. & Berberidaceae \\
\hline Berb muc & Berberis mucrifolia Ahrendt & Berberidaceae \\
\hline Betu uti & Betula utilis D. Don & Betulaceae \\
\hline Bist aff & Bistorta affinis (D.Don) Greene & Polygonaceae \\
\hline Cara jub & Caragana jubata (Pall.) Poir. & Leguminosae \\
\hline Cara suk & Caragana sukiensis C.K.Schneid. & Leguminosae \\
\hline Clem bar & Clematis barbellata Edgew. & Ranunculaceae \\
\hline Clem tib & Clematis tibetana Kuntze & Ranunculaceae \\
\hline Colo sps & Colocacea species & Araceae \\
\hline Comp sps & Composite species & Compositae \\
\hline Coto mic & Cotoneaster microphyllus Wall. ex Lindl. & Rosaceae \\
\hline Crem ren & Cremanthodium reniforme (DC.) Benth. & Compositae \\
\hline Ephe ger & Ephedra gerardiana Wall.ex Stapf & Ephedraceae \\
\hline Equi sps & Equisetum species & Equisetaceae \\
\hline Euph str & Euphorbia stracheyi Boiss. & Euphorbiaceae \\
\hline Gali sps & Galium species & Rubiaceae \\
\hline Gent ped & Gentiana pedicellata (D.Don) Griseb. & Gentianaceae \\
\hline Gera him & Geranium himalayense Klotzsch & Geraniaceae \\
\hline Gras one & Grass species & Gramineae \\
\hline Gras two & Grass species & Gramineae \\
\hline Hedy kum & Hedysarum kumaonense Benth. ex Baker & Leguminosae \\
\hline Hipp tib & Hippophae tibetana Schltdl. & Elaeagnaceae \\
\hline Jasm hum & Jasminum humile L. & Oleaceae \\
\hline Juni com & Juniperus communis Pall. & Cupressaceae \\
\hline Juni ind & Juniperus indica Bertol. & Cupressaceae \\
\hline Juni squ & Juniperus squamata Buch.-Ham. ex D.Don & Cupressaceae \\
\hline Labiatae & Labiatae species & Labiatae \\
\hline Loni ang & Lonicera angustifolia Wall. ex DC. & Caprifoliaceae \\
\hline Loni lan & Lonicera lanceolata Wall. & Caprifoliaceae \\
\hline Loni qui & Lonicera quinquelocularis Hardw. & Caprifoliaceae \\
\hline Loni tom & Lonicera tomentella Hook. f. \& Thomson & Caprifoliaceae \\
\hline Maha emo & Maharanga emodi (Wall.) A. DC. & Boraginaceae \\
\hline Myri ros & Myricaria rosea W.W.Sm. & Tamaricaceae \\
\hline Pedi tib & Pedinogyne tibetica (C.B.Clarke)Brand & Boraginaceae \\
\hline Pinu wal & Pinus wallichiana A.B.Jacks & Pinaceae \\
\hline Poly hoo & Polygonatum hookeri Baker & Liliaceae \\
\hline Poly opp & Polygonatum oppositifolium (Wall.) Royle & Liliaceae \\
\hline Pote fru & Potentilla fruticosa var. rigida (Wall. ex Lehm.) Wolf. & Rosaceae \\
\hline Prim den & Primula denticulata Sm. & Primulaceae \\
\hline Rhod lep & Rhododendron lepidotum Wall. ex D. Don. & Ericaceae \\
\hline
\end{tabular}




\section{Research paper}

\begin{tabular}{|c|c|c|}
\hline Rosa mac & Rosa macrophylla Lindl. & Rosaceae \\
\hline Rosa ser & Rosa sericea Lindl. & Rosaceae \\
\hline Rosc alp & Roscoea alpina Royle & Zingiberaceae \\
\hline Sali cal & Salix calyculata Hook. f. ex Andersson & Salicaceae \\
\hline Sali sik & Salix sikkimensis Andersson & Salicaceae \\
\hline Saus del & Saussurea deltoidea (DC.) Sch. Bip. & Compositae \\
\hline Saxi pil & Saxifraga pilifera Hook. f. \& Thomson & Saxifragaceae \\
\hline Spir can & Spiraea canescens D. Don & Rosaceae \\
\hline Stel cha & Stellera chamaejasme L. & Thymeleaceae \\
\hline Tana gra & Tanacetum gracile Hook. f. \& Thomson & Compositae \\
\hline Tara sik & Taraxcum sikkimense Hand.- Mazz. & Compositae \\
\hline Tara tib & Taraxacum tibetanum Hand.- Mazz. & Compositae \\
\hline Thal cul & Thalictrum cultratum Wall. & Ranunculaceae \\
\hline Thal fol & Thalictrum foliolosum DC. & Ranunculaceae \\
\hline Thal vir & Thalictrum virgatum Hook. f. \& Thomson & Ranunculaceae \\
\hline Thym lin & Thymus linearis Benth. & Labiatae \\
\hline Trig emo & Trigonella emodi Benth. & Leguminosae \\
\hline Vibu eru & Viburnum erubescens Wall. ex DC. & Sambucaceae \\
\hline Viol bif & Viola biflora L. & Violaceae \\
\hline
\end{tabular}

